\title{
Examining the Effect of Stakeholder Expectations and Environmental Performance on Environmental Disclosure
}

\author{
DEWI WULANSARI* \\ MAHFUD SHOLIHIN \\ Universitas Gadjah Mada
}

\begin{abstract}
This study aims to examine the effect of stakeholder expectations and environmental performance on environmental disclosures. Stakeholder expectation is characterized by the influence exerted by internal, external and intermediary stakeholder on environmental disclosure. Environmental performance is proxied by group-level direct and indirect energy consumption and greenhouse gas emissions. Meanwhile, the environmental disclosure is proxied by a disclosure score of environmental information available on firms' environmental or sustainability reports. The sample comprised of European firms extracted from the FTSEurofirst 300 Index Constituents during 2007-2011. The results suggest that neither stakeholder expectations nor environmental performance is related to or associated with environmental disclosure.
\end{abstract}

Keywords: Environmental Disclosure, Stakeholder Expectations, Environmental Performance, Environmental Accounting

Intisari: Penelitian ini bertujuan untuk menguji pengaruh ekspektasi pemangku kepentingan dan kinerja lingkungan pada pengungkapan lingkungan. Harapan pemangku kepentingan dicirikan oleh pengaruh yang diberikan oleh pemangku kepentingan internal, eksternal dan perantara pada pengungkapan lingkungan. Kinerja lingkungan diproksikan dengan konsumsi energi langsung dan tidak langsung tingkat grup dan emisi gas rumah kaca. Sementara itu, pengungkapan lingkungan diproksi dengan skor pengungkapan informasi lingkungan yang tersedia pada laporan lingkungan atau keberlanjutan perusahaan. Sampel terdiri dari perusahaanperusahaan Eropa yang diekstraksi dari FTSEurofirst 300 Index Constituents selama 2007-2011. Hasilnya menunjukkan bahwa baik harapan pemangku kepentingan maupun kinerja lingkungan terkait atau terkait dengan pengungkapan lingkungan.

Kata kunci: Pengungkapan Lingkungan, Harapan Pemangku Kepentingan, Kinerja Lingkungan, Akuntansi Lingkungan 


\section{Introduction}

Previous studies in environmental disclosure have discovered a variety of stakeholder groups or constituencies that may prompt a firm to expand disclosure of its environmental information (Cormier and Magnan, 2003; Elijido-Ten, 2007; Hong et al., 2012; Huang and Kung, 2010; Neu et al., 1998; Roberts, 1992). Neu et al. (1998) argued that environmental disclosure could be perceived as a firm's response to pressures exerted by various stakeholders or constituencies. When stakeholders exert more pressures, a firm will demonstrate more urge to satisfy and fulfill their demands by exhibiting more social and environmental responsibility. A simple way to show this responsibility is through communication, by publishing social and environmental disclosures.

Aside from stakeholder demands and pressures, firms need to take into consideration other issues regarding the promotion of environmental activities and environmental performance (Huang and Kung, 2010). Previous studies on the relationship between environmental disclosure and environmental performance have produced mix results. Some studies (e.g., Al-Tuwaijri et al., 2004; Clarkson et al., 2008; Dawkins and Fraas, 2011; Dragomir, 2010; Hughes et al., 2001; and Li et al., 1997) found a significant association between environmental disclosure and environmental performance. Other studies, however, found no relationship between firms' environmental performance and their environmental disclosure (Freedman and Jaggi, 1982; Freedman and Wasley, 1990; Ingram and Frazier, 1980; and Wiseman, 1982).

Given the little evidence on the relationship between stakeholder groups and environmental disclosure, the inconsistency between firms' environmental performance and their disclosures and the possible impact of stakeholders and environmental performance have on environmental disclosure, and this study aims to replicate the study performed by Huang and Kung (2010). Additionally, it extends the model employed by Huang and Kung as it adds environmental performance into the model and examines its relationship with environmental disclosure. It is worth noting that the reporting sample of firms listed on the Taiwan Stock Exchange (TWSE) 
employed by Huang and Kung is seen unsatisfactory and the information is very fragmented (Huang and Kung, 2010). It may be driven by insufficient environmental awareness demonstrated by local firms along with the low demands from a stakeholder in general for environmental disclosure. Taken this view into consideration, this study thus employs a sample comprised of European firms extracted from FTSEurofirst 300 Index Constituents, the definitive benchmark of blue-chip European equities (Dragomir, 2010). Additionally, this study examines the sample in five periods (2007-2011) thus becomes the empirical contribution of this study, given the vast majority of mainstream studies are focused on US data (Dragomir, 2010).

The purpose of this study is to examine whether stakeholder groups influence the disclosure of firms' environmental information and to analyze the association between firms' environmental performance and their environmental disclosures in a European context. With a total of 160 samples, we regress the disclosure score on stakeholder expectations and environmental performance after controlling for firm size and inclusion in sustainability index. The results show that neither stakeholder expectations nor environmental performance is related to or associated with environmental disclosure. Stakeholder expectations have insignificant relation with environmental disclosure. Internal stakeholder group proved not to influence the disclosure of firms' environmental information. Regardless of this insignificance, shareholders indeed negatively affect the disclosure of environmental information, implies that firms with less concentrated ownership publish environmental disclosure. While the considerable gap in the number of employees leads to the contradicting prediction. As for external stakeholder group, it is proved not to have a significant correlation with environmental disclosure. Despite this fact, government and customers are proven to affect environmental disclosure positively significantly. As for creditors and suppliers, they show a positive correlation, while competitor shows a negative correlation. It is seemingly true that even though the study has been conducted in the European context, results still support the inconsistency in the relationship between environmental performance and disclosure. Indirect and direct 
energy consumption shows a significantly positive effect on environmental disclosure, while greenhouse gas emission indicates otherwise.

The remainder of the paper is organized as follows. The next section is the literature review and hypothesis development. The following section addresses the sample selection process, measurement, and econometric model. The further section discusses the results and analysis. The last section concludes the research, outlines the limitations, as well as proposes some suggestions for future research.

\section{Theoretical Framework and Hypothesis Development}

\subsection{Stakeholder Theory}

A stakeholder is any group or individual who can affect or is affected by the achievement of the firm's objectives (Freeman, 1984). A firm, therefore, is likely to have many stakeholders, including stockholders, creditors, employees, customers, suppliers, public interest groups, government (the State), communities and society. The first thing about stakeholder theory is that "it is an explicitly systems-based view of the organization (firm) and its environment (stakeholder) which recognizes the dynamic and complex nature of the interplay between them" (Gray et al., 1996, pg. 45). As the stakeholders provide vital resources, give support and contribute to the firm, the firm has the responsibility to satisfy stakeholder demands (Wernerfelt, 1984). In other words, the more firm tends to be influenced, the higher the dependence on the external environment (stakeholder), or the stakeholder is more critical to the functioning and survival of the firm (Pfeffer and Salancik, 1978). Thus, assessing the importance of satisfying stakeholder demands is a major role of firm management to achieve the strategic objectives of the firm to respond to the different expectations of stakeholder.

As the level of stakeholder power increases, a firm must adapt on how to meet the increasing demand for the stakeholder. Once stakeholders have successfully gained influence over the firm, consequently, the firm has to acknowledge the demands of the multiple-stakeholder groups to minimize conflicting interests or to obtain their support and approval, or even to distract their opposition and disapproval (Gray et al., 1996). 
In this way, social and environmental disclosures are seen to be successful tools or medium for firms to communicate and negotiate with their stakeholder.

\subsection{Legitimacy Theory}

Another theory to explain the practice of environmental disclosure is legitimacy theory. Pfeffer (1981) stated that organizations seek legitimacy to ensure commitment and support for the organization from its society particularly stakeholders, both external and internal (as cited in Tregidga et al., 2006). They ensure the society that their business operations or activities are legitimate and fit the social values, norms, and bonds. When organizations (firms) demonstrate values that go against social values and norms, the legitimacy of such firms is potentially and substantially threatened (Brown and Deegan, 1998). This puts a basic premise of legitimacy theory, where the existence and binding power of social contract underlie the relationship between the organization (firm) and society (stakeholders). Also, legitimacy can directly rely on the concept of a social contract. If the firm failed to meet its social contract with the society, it would then be perceived as breaching the social contract thus the survival of the firm might be threatened. When this condition happens, the society will revoke the contract to continue the firm's operation and impose sanctions on the firm. Sanctions can be in the form of, for example, consumers reducing the demand for the products, factor suppliers eliminating the supply of labor and financial capital and constituents lobbying government for increased taxes, fines, or laws to prohibit those actions which do not attune to the expectations of the society (Deegan, 2002).

Such sanctions will endanger the life continuation of the firm. Thus, a firm will seek to establish congruence between the social values associated with or implied by their activities and the norms of acceptable behavior in the more extensive social system of which they are a part (Dowling and Pfeffer, 1975). When this congruency is not established, there is. Therefore, a legitimacy gap, which arose from an actual failure of a firm's performance or firm's actual behavior didn't meet the social values and norms. The legitimacy gap will fluctuate or even grow when the firm doesn't 
make any changes to answer the demand to change from the relevant publics' expectations. Then it is generally agreed, that if a firm changes its activities, attempts, or behavior to alter society's expectations of its activities, these must be accompanied by disclosures (Cormier and Gordon, 2001 and O'Donovan, 2002). This way, it can be concluded that social and environmental disclosures can be employed to close a legitimacy gap (Lindblom, 1994 as cited in Gray et al., 1996). Furthermore, these disclosures may then be conceived as a response to the environmental factors where they are used to legitimize the firm's activities and behavior.

\subsection{Environmental Disclosure in a Stakeholder Context}

Over the past decades, the number of firms who have disclosed their environmental information either as part of their annual report or stand-alone environmental reports has been increasing. This increasing trend comes along with the findings of numerous studies which also suggested that environmental reports of all kinds continue to increase over time (Deegan et al., 2002; Elijido-Ten et al., 2010; Gray et al., 1995). There are, as noted by Huang and Kung (2010), previous studies that have focused on the importance of stakeholder pressure in affecting firms' actions as to their social and environmental disclosures and the degree of these disclosures is influenced by the demands of multiple-stakeholder groups.

Employing Ullmann's model, Roberts (1992), empirically tested the ability of stakeholder theory to explain the firm's social responsibility disclosure. Finding supported this model concluded a significantly positive correlation between stakeholder power, strategic posture and economic performance to the levels of corporate social disclosure. Meanwhile, still adopting Ullmann's model is Elijido-Ten (2004), whose findings suggest that the main determinants in providing environmental disclosures are the level of environmental concern by the top management and the government's power to sanction companies.

Gray et al. (1995) found some evidence that companies were using environmental disclosures as an attempt to negotiate the concept of 'environment' and to determine the companies' relationships with society in general and the environmental pressure 
groups in particular. Harvey and Schaefer (2001) used a comparative case study approach to examine the relationship of six U.K. water and electrical utilities with their green stakeholders. Institutional stakeholders (e.g., government and regulators) were found to be the most influential groups although customers and the general public were also considered important.

A more recent study by Elijido-Ten et al. (2010), who conducted an experimental study in Malaysia, found that the perceived significance of an environmental event has a significant impact on environmental disclosure decisions. Huang and Kung (2010) investigated stakeholder expectations associated with a firm's environmental disclosure in Taiwan. Their result shows that the level of a firm's environmental disclosure is significantly affected by stakeholder groups' demands.

From all of the findings above and results above, it can be concluded that multiple-stakeholder demand, pressure, and power to really influence how firms form strategies, react and behave in a way to exhibit their social responsibility actions and behavior to meet those demands. One of those actions is conducted through publishing and disclosing social and environmental information, where environmental disclosure is then seen as a means by which firms communicate and negotiate to their stakeholder groups. Replicating the study by Huang and Kung (2010), this study analyzes how firms respond to stakeholder demands thus will shed light on motives that prompt firms to provide environmental disclosure, besides at the same time extending it by exploring how environmental performance associated with environmental disclosure.

\subsection{The Inconsistent Results in the Studies between Environmental Performance and Environmental Disclosure}

Few studies in the area of environmental performance provided a brief and straightforward definition of the environmental performance; however, it is worth to note that defining corporate environmental performance is not a straightforward task (Ilinitch et al., 1998). International Standard Organization and European Community have successfully expressed the definitions of environmental performance as follows: 
measurable results of an organization's management of its environmental aspects, results can be measured against the organization's environmental policy, environmental objectives, environmental targets and other environmental performance requirements; and results of an organization's management of its environmental aspects (results may be measured against the organization's environmental policy, objectives, and targets) (ISO 14031 and EC Regulation No 761/2001 as cited in Perotto et al., 2008, pg. 518).

According to Buhr (1995), a firm chooses a level of environmental performance along with a spectrum of possible behaviors and a level of environmental disclosure. The selected level of environmental disclosure may have everything or nothing in common with the actual environmental performance. The conflicting evidences between environmental disclosure and environmental performance have been wellilluminated in previous studies (Al-Tuwaijri et al., 2004; Buhr, 1995; Clarkson et al., 2008; Dawkins and Fraas, 2011; Deegan and Rankin, 1997; Dragomir, 2010; Hughes, 2001; Ingram and Frazier, 1980; Mobus, 2005; Patten, 2002; Rockness, 1985; and Wiseman, 1982).

Ingram and Frazier (1980), Wiseman (1982) and Rockness (1985) are those who found that no relationship existed between the measured contents of the firms' environmental disclosures and the firms' environmental performance. However, a contrary result presents a significant association between environmental performance and environmental disclosure (Al-Tuwaijri et al., 2004; Clarkson et al., 2008; Dawkins and Fraas, 2011). Clarkson et al., (2008) and Dawkins and Fraas (2011) captured the positive association between environmental performance and environmental disclosure, implying that superior environmental performers are more anticipated in disclosing environmental information. On the contrary, other findings show that it is poor performers who make the most disclosures, unveiling the significant negative association between environmental performance and disclosure (Dragomir, 2010; Hughes et al., 2001; Mobus, 2005; Patten, 2002).

\subsection{Hypothesis Development}


Replicating study by Huang and Kung, stakeholders are classified into three groups:

\section{Internal Stakeholder}

Huang and Kung classified internal stakeholder groups into shareholders and employees. As found by Malone, Fries and Jones, 1993, there is a positive association between the number of shareholders and information disclosed in the annual report (as cited in Elijido-Ten, 2004). Additionally, the level of ownership concentration (blockholder ownership) may also influence the level of disclosure. However, the association between them is negative, as portrayed by Christopher and Hassan, 1996; Craswell and Taylor, 1992; and Frost, 1999 (as cited in Elijido-Ten, 2004). It suggests that the less concentrated or more diffused or dispersed the ownership structure of a firm, the higher the likelihood of that firm to disclose information. Meanwhile, block holder itself is defined as "the proportion of ordinary shares owned by substantial shareholders (shareholding with equity of 5\% or more)" (Eng and Mak, 2003, pg. 326).

Employees, other than owners, customers, and suppliers; is distinguished as primary stakeholders of a firm since it is one of the primary providers of firm's resources (Elijido-Ten, 2007). Firms with a more significant number of employees will have a more significant effect on environmental policies and demand for transparent environmental information as to prevent the compromising of their rights and interests. Furthermore, concluded by Gamerschlag et al. (2011), the number of employees does indeed affect the disclosure of social, environmental information. Based on the explanation above, a hypothesis is constructed as follows:

Ha: Environmental disclosure is associated with internal stakeholders' expectations and demands

\section{External Stakeholder}

As for external stakeholder groups, Huang and Kung classified them into government, creditors, consumers, suppliers, and competitors. Among external stakeholder groups, the government is said to have the enormous effect on firms. Firms who violate environmental regulations and laws will be fined and asked to pay 
penalties. In this case, large firms are considered to carry more burden and pressure from their society towards social and environmental matters. It is in the best interest of the firms to avoid government intervention by considering both the regulations and the expectations of its stakeholders to preserve its business activities (Elijido-Ten, 2004). Creditors, as argued by Roberts (1992), have a more significant influence on corporate policies, in this case, environmental policies, when the borrowing firms have high financial leverage. The more the firm depends on debt financing, the more likely it is to disclose environmental information to be seen as a firm with lower risk (ElijidoTen, 2004). While these two findings support a positive association between creditors and environmental disclosure, Belkaoui and Karpik (1989); Cormier and Gordon (2001); and Cormier and Magnan (1999) obtained a negative association. Different from Huang and Kung who predicted only positive association, this study will be open for possibilities (+/-) in this association.

As for suppliers, they will demand more transparent environmental information to prevent themselves being linked to bad environmental performance. Meanwhile, for customers, Huang and Kung (2010) added that customers' engagement on firms' environmental disclosure and its contents is an indication that environmental performance is being intended to serve customers. The unavailable data of advertising fees drives this study to use sales turnover as a proxy variable for customers. The use of sales turnover is supported by Hong et al. (2012), who mentioned that customers' power comes from themselves since they provide revenues (sales) for firms. Thus, when firms neglect their responsibility to disclose environmental information to customers, the survival of these firms might be endangered.

As for the competitor, the proxy variable used is market share. Firms with a higher market share may expose a more significant influence in controlling the market, and this will cause firms to attain more attention from their society and other competitors. To handle this, firms will then reveal more information on their environmental disclosure. Based on the explanation above, a hypothesis is constructed as follows: 
$\mathrm{Ha}_{2}$ : Environmental disclosure is associated with external stakeholders' expectations and claims

\section{Intermediary Stakeholder}

Intermediary stakeholder groups are classified into environmental protection organizations and accounting firms. According to Deegan and Gordon (1996), firms within higher sensitivity industries will increase their levels of environmental disclosure under some pressure from an environmental organization. Meanwhile, Huang and Kung (2010) also added that the monitoring strength of auditors affects the quality of information disclosure. Previous research suggested that the Big 4 accounting firms (auditors) provide superior quality assurance as compared to non-Big four auditors (Teoh and Wong, 1993 and Watkins et al., 2004 as cited in Huang and Kung, 2010). However, the samples used in this study were selected from the most polluting industrial sectors in Europe, indicating that they are environment-sensitive firms. Moreover, after checking at OneSource Global Business Browser financial database, all of the sample firms were audited by the Big 4 auditors. These reasons lead this study to exclude the testing of intermediary stakeholders and its influence on environmental disclosure.

Environmental reporting or disclosure as we have discussed above is described by FEE as a report covers the preparation and provision of information, by management, for the use of multiple stakeholder groups (internal and external), on the environmental status and performance of their firms or organizations. Consequently, firms' environmental disclosure should have reflected its environmental performance. Meanwhile, this ideal definition sometimes doesn't go along with the current real practice. Some previous studies noted the inconsistency in the association or relationship between environmental performance and environmental disclosure. This study, however, tries to shed light in environmental disclosure study and contribute in a way as it examines the merely empirical evidence on European environmental performance and disclosure studies. The next hypothesis is constructed as follows:

H1: Environmental disclosure is associated with firms' environmental performance 


\section{Research Method}

\subsection{Sample Selection Process}

The population used in this study is firms listed on the FTSEurofirst 300 Index from 2007-2011, with the initial sample comprised of 254 firms. The FTSEurofirst 300 Index, created by FTSE Group and NYSE Euronext, is the definitive benchmark of blue-chip pan-European equities. Meanwhile, the designated periods were selected based on the establishment of European Pollutant Release and Transfer Register (Regulation 2006/166/EC), which give access of environmental information of European firms; and Decision 2007/589/EC, the amendment of Decision 2004/156/EC, which require firms to fulfill a complete, consistent, transparent and accurate monitoring and reporting of greenhouse gas emissions. From this population, the sample is extracted by selecting four most polluting industrial sectors in Europe (based on European Pollution Release and Transfer Register: energy, production, and processing of metals, mineral/mining and chemical industry), resulting in 42 sample firms. These four industrial sectors are chosen regarding sample homogeneity and at the same time to break the limitations in Dragomir's findings (2010), as he stated that sample heterogeneity was regarded as a significant flaw of the final output. The purposive sampling method was utilized to select the sample. We removed from consideration ten firms that did not publish an annual report, environmental information within the annual report or stand-alone environmental/ sustainability report during 2007-2011 and did not have sufficient data in financial database Osiris and OneSource Global Business Browser. The final sample comprised of 32 firms for five periods (2007-2011).

\subsection{Measurement}

The dependent variable in this study is environmental disclosure, measured in the annual report or stand-alone sustainability/corporate responsibility report using content analysis. Although this study replicates the research by Huang and Kung 
(2010), an environmental disclosure index developed by Dragomir (2010) is utilized. The environmental disclosure index is chosen to fit this study best in that it has been used by Dragomir to test the European sample. This index was developed based on the 3.1 version of GRI Sustainability Reporting Guidelines which is acknowledged as the best practice on the environmental side and the most widely adopted guidelines by firms around the world.

Reporting Guidelines are an incipient scoring system, and the topics in these guidelines are capable of being treated at various levels of comprehensiveness, ranging from being mentioned briefly to being fully documented quantitatively (Morhardt et al., 2002). Thus, this study incorporates these topic guidelines into a scoring system and "assign a range of points indicating how thoroughly the topics were discussed, also use a five-level ordinal scale to measure the degree of voluntary environmental disclosure, ultimately seeking to award quantitative, comparable and benchmarked information against vague narratives" (Dragomir, 2010, pg.369) as shown in the table below.

To construct a scoring system from the guidelines, Dragomir identified every item regarded as environment performance indicators section of the GRI guidelines resulting in 26 items of disclosure, for a maximum 62 points, as can be seen in table 3 .

\subsection{Independent Variable: Stakeholder Expectations}

As one of the independent variables, stakeholder expectations, is developed into a reliable proxy by Huang and Kung (2010). However, due to the unavailability of data regarding advertising fees, this study otherwise uses sales turnover as the proxy variable for customers. In support of this idea is Hong et al. (2012), who mentioned that customers' power comes from themselves since they provide revenues for firms. Furthermore, regarding fines and penalties as the proxy variable of government, it is believed that what Huang and Kung refer to fines and penalties are not limited only to the amount which has been paid. They clearly stated "...past and present fines and penalties; and potential fines and penalties..." (pg.443) and "...fines and penalties and the future environmental expenses..." (pg.446). Henceforth, this study uses 
environmental provision (in which past, present and potential fines and penalties are included) for the proxy variable of government. The proxy variables for all of the stakeholder groups are shown at the following table.

\subsection{Independent Variable: Environmental Performance}

This study follows a recent study by Dragomir (2010) who developed a reliable proxy to measure environmental performance quantitatively. Two measures were employed after being normalized for firm size. The normalization is required to enable comparison between firms of different size (Trucost.com, 2009 as cited in Dawkins and Fraas, 2011). The two measures are:

1. Group-level direct and indirect energy consumption data were collected from annual sustainability reports in gigawatt-hours $(\mathrm{GWh})$ and normalized by firm size (ECTA). However, some companies reported in tonnes of oil equivalent (toe), in megajoules, or in metric tonnes, for which the figures were converted to GWh using the tool available on the International Energy Agency's website (www.iea.org). There are 147 valid observations in this category.

2. Group-level greenhouse gas emissions in kilotons of $\mathrm{CO} 2$ equivalent were collected from data presented in annual sustainability reports $\left(\mathrm{CO}_{2} \mathrm{TA}\right)$. Decision 2004/156/EC, as amended by Decision 2007/589/EC, has laid down guidelines for firms in Europe to fulfill a complete, consistent, transparent and accurate monitoring and reporting of greenhouse gas emissions (Dragomir, 2010). As a consequence, there are more available data on this category, 155 valid observations. This indicator was also normalized by firm size.

These two measures are left with the predicted sign of $+/$ - caused by the inconsistent results in the study between environmental performance and environmental disclosure.

\subsection{Control Variables, Firm Size and Inclusion in the Sustainability Index}

Previous studies (e.g., Cowen et al., 1987; Deegan \& Gordon; 1996; Gray et al., 1995; Hackston \& Milne, 1996; Patten, 1992 as cited in Patten, 2002) found a significant relationship between firm size and the extent of environmental disclosure. 
This study particularly proxy firm size as total assets, in line with Hackston and Milne, 1996; and Branco and Rodrigues, 2008 (as cited in Khemir and Baccouche, 2010). However, the findings are still debatable in that Dragomir (2010) and Elijido-Ten (2004) documented a significant positive association; while Roberts (1992) documented negative association. Because the firms come from different countries in Europe with different currencies, the amount for total assets will be converted to Euro $(€)$ at the appropriate exchange rate for the end of the fiscal year based on OneSource Global Business Browser database, to ensure comparability.

Inclusion in a sustainability index (FTSE4Good Index) is a dummy variable which equals one for the group belonging to this index. The FTSE4Good Index series is a series of ethical investment stock market indices launched in 2001. It is designed to objectively measure the performance of companies that meet globally recognized corporate responsibility standards. Due to the small to medium effect between the inclusion in sustainability index and environmental disclosure, this control variable is signed $+/$-.

\section{Econometric Model}

$$
\begin{aligned}
& E D_{i t}=\beta_{0}+\beta_{1} O W N_{i t}+\beta_{2} E M P_{i t}+\beta_{3} \text { FINES }_{i t}+\beta_{4} L E V_{i t}+\beta_{5} \text { SALES }_{i t}+ \\
& \beta_{6} I N V T_{i t}+\beta_{7} M K T S_{i t}+\beta_{8} E C T A_{i t}+\beta_{9} \text { CO2TA }_{i t}+\beta_{10} S_{Z I} E_{i t}+\beta_{11} \text { FTS }_{i t}+ \\
& u_{i t}
\end{aligned}
$$

The variables in the regression above are defined as follows:

$\mathrm{ED}=$ the score of total environmental disclosure obtained by performing a content analysis based on GRI-inspired environmental disclosure index (table 3.3).

OWN = the blockholder ownership, measured by adding up the shareholding of the substantial shareholders (own $>5 \%$ from the total ordinary shares outstanding). $\mathrm{EMP}=$ the number of employees.

FINES $=$ past, present and potential fines and penalties (environmental provision) in regard to environmental protection regulations. Net sales deflate the amount of environmental fines and penalties. 
$\mathrm{LEV}=$ the degree of financial leverage, measured as the ratio of the earnings before interest and taxes (EBIT) divided by EBIT minus interest expense as of fiscal year-end.

SALES = natural logarithm of sales turnover.

INVT = inventory turnover, measured as the ratio of cost of goods sold and average inventory as of fiscal year-end. The amount is scaled by industry-average inventory turnover ratio.

MKTS $=$ market share, measured as net sales divided by the total sales of the industry.

$\mathrm{ECTA}=$ total direct and indirect energy consumption in GWh, normalized by a total asset.

$\mathrm{CO}_{2} \mathrm{TA}=$ greenhouse gas emission $\left(\mathrm{CO}_{2}\right.$ emission equivalent $)$, normalized by a total asset.

SIZE $=$ natural logarithm of total asset value in a million Euros $(€)$ measured as of the end of the fiscal year 2007-2011.

FTSE $=$ the inclusion in the sustainability index (FTSE4Good Index), measured using a dummy variable $(1=$ inclusion in the index, $0=$ not included in the index $)$.

$\beta_{0.12}=$ coefficient of regression.

$\mathrm{i}=$ the 32 firms.

$\mathrm{t} \quad=2007-2011$.

uu

$$
=\text { error term. }
$$

This study utilizes a panel (pooled) design which is considered appropriate to break the limitations induced by cross-sectional design as expressed by Dragomir. Using Eviews 6.0, fixed effects model (FEM) is chosen as the best model for analyzing the data after went through the restricted F-Test and Hausman Test. It is worth noting that there are missing data in this study, to mention 25 missing data in environmental performance variable (23 missing data in ECTA and five missing data in $\mathrm{CO}_{2} \mathrm{TA}$ ). These missing data were replaced by zero replacement and average replacement. The fixed effects regression results from these two replacements are the 
same; except the probability of energy consumption (ECTA) becomes insignificant when using average replacement. It may be due to a large number of missing data is found in ECTA itself. Henceforth, this study replaced the missing data with 0 (zero) to distinguish the firms who do not disclose their energy consumption information.

\section{Results}

\subsection{Environmental Disclosure Scoring}

This index consists of six categories, a total of 26 items of disclosure, for a possible 62 points. However, the maximum score of 42 is attributed to only one firm. This result may be due to few findings regarding data measurement techniques and bases for calculations which are inadequately described in environmental/sustainability reports (score 3). Moreover, the absence of score 4 in any of the 160 sample also contributes to the relatively low mean disclosure score of 26.4 . It can be inferred from this result that the sample firms have environmental disclosure comparability for the reporting entity and multiple periods, despite the lack of conformity with the guidelines. Meanwhile, the lowest score of ten indicates that a minimal level of environmental/sustainability reporting was present across the sample, although all firms in the sample report at least rudiments of environmental concern (Dragomir, 2010). This score is two times higher than the lowest score of what Dragomir found on his study, suggesting a narrower range of the total disclosure scores.

The first category, environmental governance and credibility aspect, focus on disclosures about a firm's governance structure and management systems put in place concerning environmental protection. The items in this category are the most attained ones by firms (68.75-100\%). The reason for this finding may be because firms tend to elaborate more on their environmental policies and prefer statements rather than numbers (see also EN6, EN18, and EN26). On the other hand, under the category of material, the percentage of materials used that are recycled input materials is the item least attained by firms (15.6-37.5\%). The quantity of information provided for EN2 is 
usually very scarce because recycling is mostly implemented only to waste, in which the outcome will not be used as input materials.

According to Krippendorff (1980), there are two basic criteria to be fulfilled in content analysis, reliability and validity. He identified three types of reliability: stability, reproducibility, and accuracy. The results of the coding process are stable in that the initial coding of environmental information was subject to a later verification (Dragomir, 2010). Two coders conducted content analysis in this study. Nonetheless, the unavailability of the second coder to content analyze the extension of the sample (initial sample was only 96 for 32 firms from 2007-2009) leads to verification of 96 sample from 2007-2009 only. Another coder did not replace the second coder because conflicting coding may arise from cognitive differences between the coders.

Meanwhile, reproducibility, sometimes called inter-coder reliability, refers to the extent to which content classification produces the same results when the same text is coded by more than one coder (Dragomir, 2010). As for sample firms' environmental disclosure scores from 2007-2009, there were very few differences in the results among the two coders, suggesting the presence of reproducibility. While accuracy, according to Dragomir, refers to the extent to which the classification of text corresponds to a standard or norm. This study exhibits accuracy, in that the coding scheme corresponds to the GRI environmental indicators. As for validity, it can be seen from the results of this study.

\subsection{Regression Results}

The econometric model suggested above is appropriate to be used in this study. This condition applies because R2 > Adj.R2 and proves by $0.811>0.743$. R-squared depicts the amount of variance explained in the dependent variable by the predictors or independent variables (Sekaran, 2010). However, it causes a bias towards the number of independent variables in the model. Every addition of independent variable into the model will cause the increasing of R2, despite the degree of significance towards $\mathrm{Y}$. Thus, Adjusted R2 is chosen to explain this variance, instead of R2. The Adj.R2 value of 0.743 means that independent variables provide $74.3 \%$ required information to 
predict the variation of the dependent variable. Meanwhile, the rest $26.7 \%$ is explained by other factors outside the model of this study.

a Coefficient for each variable is shown, with a p-value in parentheses.

$\mathrm{b} * \mathrm{p}<0.10 ; * * \mathrm{p}<0.05 ; * * * \mathrm{p}<0.01$

Although stakeholder expectations and environmental performance (controlled by size and inclusion in sustainability index) have a simultaneous joint effect toward environmental disclosure (F-Stat [11.966] > F-Table [1.549]), the result is different when each of the independent variables is analyzed.

\subsection{Internal Stakeholders' Expectations and Environmental Disclosure}

From table 4 in Appendix, it is concluded that there is no association between internal stakeholders (shareholders and employees) and environmental disclosure; hence the first hypothesis $\left(\mathrm{Ha}_{1}\right)$ is rejected $(-0.014845, \mathrm{p}=0.7199)$. Even though insignificant, the relationship between shareholders and environmental disclosure is negative, still in line with the predicted sign. The negative coefficient suggests that the more diffused or dispersed the ownership structure of a firm, the more shareholders demand for a broader range of information about corporate activities, particularly social and environmental activities. Therefore, the likelihood of that firm to disclose information is also greater. Not only applies to Taiwan (Asia) context, but this finding also applies in the European context, although the statistical result is not significant. This insignificantly negative association is consistent with Elijido-Ten's (2004), Liu and Anbumozhi (2009) and Roberts' (1992) findings. The ownership of most European firms is mainly in the hands of individuals and is frequently family controlled (Enriques and Volpin, 2007 as cited in Elmans, 2012). It implies that the concentration of ownership is high. Thus, the negative relationship is exhibited. However, as supported by Elijido-Ten (2004), it's not the level of ownership dispersion that affects the disclosure of environmental information but perhaps more the concern for the environment by the majority shareholders. 
Against the predicted sign, a negative yet insignificant relationship is documented between the number of employees and environmental disclosure (-4.68E-05, $\mathrm{p}=0.1652$ ). One explanation of this finding is "executives/managers think employees would rather see the firm maintain its viability and longevity rather than contribute to the broader society" (Aerts et al., 2006, pg. 181). It is observed during the scoring of environmental disclosure that firms with the relatively high disclosure scores are not firms with a high number of employees. The highest score (42) is obtained by a firm which has 78,313 employees, while the firm which is the second highest in the number of employees $(315,867)$ only obtained a total score of 13 (the lowest score is ten across the sample). Other than this, a wide gap in the number of employees may contribute to the negative statistical result (the lowest-highest number of employees: 2,345-331,266 employees). As supported by Wagner (2005), "the short time-period of the analysis cannot fully rule out that some longer-term positive effects are not accounted for" (pg. 181) hence the negative relationship may be less severe than what is found at this study.

Overall, there are only two out of five stakeholders demonstrate a significant association with environmental disclosure. Henceforth, the second $\left(\mathrm{Ha}_{2}\right)$ hypothesis is rejected while the null hypothesis is accepted. Firms obliged to fines and penalties, or provide a large amount of environmental provision tend to disclose more positive environmental information (147.9582, $\mathrm{p}=0.0017)$. The significantly positive relationship indicates firms aim to legitimate their negative behavior (of receiving fines and penalties) to be perceived as an excellent environmental performer. This result is in line with legitimacy theory, in that low performer discloses environmental information. Using sample from environmentally sensitive industrial sectors, this study portrays the same result as those of prior studies (Elijido-Ten, 2004; Liu and Anbumozhi, 2009). The findings present evidence that firms from environmentally sensitive industrial sectors provide more environmental disclosures as a way to minimize or avoid government sanctions or penalties, thus suggesting a positive relationship in between. 
Huang and Kung (2010) suggested that creditors will demand more information be disclosed when a firm faces high financial risks as a mean to keep themselves informed as to the latest corporate developments and to make their economic decisions accordingly. However, opposite finding suggests that creditors fail to capture the significant relationship with environmental disclosure $(0.393756, \mathrm{p}=0.548)$. Despite the insignificant result, the correlation in between is positive, in line with ElijidoTen's (2004), Huang and Kung's (2010) and Roberts' (1992) findings. As further explained by Roberts (1992), the creditors' power depends upon the degree to which a firm relies on debt financing. In spite of the highly levered sample used in this study which implies that creditors can greatly determine the firm's business activities, the correlation appears to be insignificant. The statistical result in this study is consistent with Liu and Anbumozhi's (2009) finding.

As for customers, sales turnover can indeed replace the proxy suggested by Huang and Kung, advertising fees. A significantly positive relationship between customers and environmental disclosure explains that customers, the primary stakeholder of a firm who mainly affects its revenue and survival, can substantially affect the environmental information disclosed by firms (4.839244, $\mathrm{p}=0.0274)$. The more significant amount of sales a firm gained from its customers, the higher the likelihood of that firm to disclose environmental information. Therefore, this finding supports Huang and Kung (2010) in that customer is capable of affecting firms' environmental disclosure.

Suppliers provide firms with vital resources, in return, suppliers will demand to see more transparent environmental information to keep themselves updated on the latest corporate environmental strategies (Huang and Kung, 2010). Nonetheless, the statistical result captured an insignificant association between suppliers and environmental disclosure $(1.227919, \mathrm{p}=0.4546)$. One reason which may lead to this result is the finding by Wilmshurst and Frost (2000) who surveyed with the respondents of Australian companies. The finding documented that firms' concerns toward supplier ranked as being of least importance by the respondents. Aside from 
this survey, an insignificant association is well captured in the empirical study conducted by Hong et al. (2012).

As for competitors, an insignificant and negative relationship present between competitors and environmental disclosure (-44.90012, $\mathrm{p}=0.6029)$. Although no significant association is found, the negative result in this study demonstrates that it firms even with low market share who disclose environmental information. Wilmshurst and Frost (2000) captured a negative association in competitors' response to environmental issues. Other than this, no evidence documented similar result. It may be due to the little evidence on the relationship between competitor and environmental disclosure; and the classification of competitors as one of the secondary or adversarial stakeholders which draws little attention from scholars.

\subsection{Environmental Performance and Environmental Disclosure}

The conflicting results in the relationship between environmental performance and environmental disclosure have led to the testing of these two variables in the European context with the expectation to follow either the positive or negative-stream. First developed and tested by Dragomir (2010), the two measures of environmental performance, energy consumption and $\mathrm{CO} 2$ emission released, surprisingly contradict each other. Whereas energy consumption normalized by total assets (ECTA) demonstrates significantly positive result (1.001929, p=0.0337), CO2 emission released normalized by total assets (CO2TA) exhibits negative and insignificant finding $(-1.20437, \mathrm{p}=0.5159)$. These findings, however, lead to the conclusion that the third hypothesis $\left(\mathrm{Ha}_{3}\right)$ is rejected thus environmental performance has no significant relationship with environmental disclosure (in line with Freedman and Jaggi, 1982; Ingram and Frazier, 1980; and Wiseman, 1982). This finding may partly be because GRI Sustainability Reporting Guidelines has not been made into a mandatory guideline in Europe. Thus, many firms are found not fully reporting their environmental performance information.

However, regardless its insignificance, the contradicting coefficient between the two measurements of environmental performance will be discussed. The statistical 
result of the first measurement, ECTA, indicates that good performer with a low energy consumption discloses environmental information. In other words, superior environmental performers are more forthcoming in disclosing environmental information. Meanwhile, the negative association of CO2TA explains that it is low performers who disclose environmental information. To reduce the risk possessed by their stakeholders (for conducting bad environmental performance and showing 'bad' behavior), firms thus attempt to legitimize their behavior by disclosing environmental information.

Both control variables, firm size (total assets) and inclusion in sustainability index (FTSE4Good), indicate insignificant results. Thus, firm size $(-1.831862$, $\mathrm{p}=0.4841)$ and inclusion in sustainability index $(0.498027, \mathrm{p}=0.6949)$ cannot be used as control variable. A similar result was also pointed out by Roberts (1992), in that firm size is not supported as a control variable on the level of environmental disclosure.

\section{Conclusion, Implication, and Limitation}

After reviewing the statistical facts, we can conclude that neither stakeholder expectations nor environmental performance is related to or associated with environmental disclosure. Internal stakeholder group does not influence the disclosure of firms' environmental information. Regardless of this insignificance, shareholders indeed negatively affect the disclosure of environmental information, implies that firms with less concentrated ownership publish environmental disclosure. While the huge gap in the number of employees' leads to the contradicting prediction. As for external stakeholder group, it is proven that it has no significant correlation with environmental disclosure. Despite this fact, government and customers are proven to affect environmental disclosure positively significantly. These stakeholders, based on Roberts' (1992), are primary stakeholders of a firm. The significant findings suggest that legitimacy theory applies in this study in that it is firms with a high amount of fees and provision of environmental matters who disclose environmental information. 
Meanwhile, regarding the continued viability of its business activity, the firm discloses environmental information to answer the differing demands of its stakeholders. As for creditors and suppliers, they show a positive correlation, while competitor shows a negative correlation. It is seemingly true that even though the study has been conducted in the European context, results still demonstrate contradicting evidence in the relationship between environmental performance and disclosure. ECTA shows a significantly positive result while CO2TA shows otherwise.

The implications of this study are limited by research design in general. More specifically, the scope and number of samples were limited to only 32 European firms listed on the FTSEurofirst 300 Index. Therefore, the result of this study is limited to the European context and cannot be generalized into another setting. Secondly, no absolute measurement is found in the environmental performance literature. Therefore, it may cause the contradicting results in the studies between environmental performance and disclosure.

Moreover, it is also possible that there are anomalous samples or sample year in which most companies are performed well or poorly. Lastly, instead of Huang and Kung's environmental disclosure scoring-index, this study uses Dragomir's. This reason is suspected to cause the different results from Huang and Kung's. Thus, these two studies cannot be compared.

Future studies might be worth conducted in Indonesia context as little evidence is found in the study of stakeholder and environmental disclosure. Additionally, to prove and compare the results between Huang and Kung (2010) and the model of this study, it is suggested to utilize the environmental disclosure scoring-index developed by Huang and Kung.

\section{References}

Aerts, W., Cormier, D., Gordon, I.M., and Magnan, M. 2006. Performance Disclosure on the Web: An Exploration of the Impact of Managers' Perceptions of Stakeholder Concerns. The International Journal of Digital Accounting Research, 6 (12): 159-194. 
Al-Tuwaijri, S.A., Christensen, T.E., and Hughes II, K.E. 2004. The Relations among Environmental Disclosure, Environmental Performance, and Economic Performance: A Simultaneous Equations Approach. Accounting, Organizations and Society, 29: 447471.

Belkaoui, A., and Karpik, P. 1989. Determinants of the Corporate Decision to Disclose Social Information. Accounting, Auditing and Accountability Journal, 2 (1): 36-51.

Brown, N., and Deegan, C. 1998. The Public Disclosure of Environmental Performance Information - A Dual Test of Media Agenda Setting Theory and Legitimacy Theory. Accounting \& Business Research, 29 (1): 21-41.

Buhr, N. (1995). Environmental Performance, Legislation, and Annual Report Disclosure: The Case of Acid Rain and Falconbridge. Accounting, Auditing and Accountability Journal, 11 (2): 163-190.

Clarkson, P.M., Li, Y., Richardson, G.D., and Vasvari, F.P. 2008. Revisiting the Relation between Environmental Performance and Environmental Disclosure: An Empirical Analysis. Accounting, Organizations and Society, 33: 303-327.

Collison, D., and Slomp, S. 2000. Environmental Accounting, Auditing, and Reporting in Europe: The Role of FEE. The European Accounting Review 2000, 9 (1): 111-129.

Cormier, D. and Gordon, I.M. 2001. An Examination of Social and Environmental Reporting Strategies. Accounting, Auditing and Accountability Journal, 14 (5): 587-616.

Cormier, D., and Magnan, M. 1999. Corporate Environmental Disclosure Strategies: Determinants, Costs, and Benefits. Journal of Accounting, Auditing, and Finance, 14 (3): 429-451.

Cormier, D., and Magnan, M. 2003. Environmental Reporting Management: a Continental European Perspective. Journal of Accounting and Public Policy, 22: 43-62.

Dawkins, C., and Fraas, J.W. 2011. Coming Clean: The Impact of Environmental Performance and Visibility on Corporate Climate Change Disclosure. Journal of Business Ethics, 100: 303-322.

Deegan, C. 2002. Introduction: The Legitimising Effect of Social and Environmental Disclosures - a Theoretical Foundation. Accounting, Auditing and Accountability Journal, 15 (3): 282-311.

Deegan, C., and Gordon, B. 1996. A Study of the Environmental Disclosure Practices of Australian Corporations. Journal of Accounting and Business Research, 26 (3): 187199.

Deegan, C., and Rankin, M. 1997. The Materiality of Environmental Information to Users of Annual Reports. Accounting, Auditing \& Accountability Journal, 10 (4): 562 - 583.

Dowling, J., and Pfeffer, J. 1975. Organizational Legitimacy: Social Values and Organization Behavior. Pacific Sociological Review, 18 (1): 122-136. 
The Indonesian Journal of Accounting Research - September, Vol. 20, No.3, 2017.

Dragomir, V.D. 2010. Environmentally Sensitive Disclosures and Financial Performance in a European Setting. Journal of Accounting \& Organizational Change, 6 (3): 359-388.

Elijido-Ten, E. 2004. Determinants of Environmental Disclosure in a Developing Country: an Application of Stakeholder Theory. Paper presented at the Asia Pacific Interdisciplinary Research in Accounting (APIRA), Singapore, 2004.

Elijido-Ten, E. 2007. Applying Stakeholder Theory to Analyze Corporate Environmental Performance: Evidence from Australian Listed Companies. Asian Review of Accounting, 15 (2): $164-184$.

Elijido-Ten, E., Kloot, L., and Clarkson, P. 2010. Extending the Application of Stakeholder Influence Strategies to Environmental Disclosures: An Exploratory Study from a Developing Country. Accounting, Auditing and Accountability Journal, 23 (8): 1032 1059 .

Elmans, S.C. 2012. Ownership Structure and Voluntary Disclosure in Europe. (Unpublished Master Thesis). Erasmus School of Economics, Netherland.

Eng L.L., Mak Y.T. 2003. Corporate Governance and Voluntary Disclosure. Journal of Accounting and Public Policy, 22: 325-345.

Environmental Working Party. 2000. Towards a Generally Accepted Framework for Environmental Reporting. Brussels: Fédération des Experts Comptables Européens (FEE).

Fédération des Experts Comptables Européens (FEE). 1999. Providing Assurance on Environmental Reports. Brussels: FEE.

Freedman, M., and Jaggi, B. 1982. Pollution Disclosures, Pollution Performance and Economic Performance. The International Journal of Management Science, 10 (2): 167-176.

Freeman, R. E. (1984). Strategic Management: A Stakeholder Approach (Chapter 2). Retrieved from http://books.google.co.id/books?id=NpmA_qEiOpkC\&pg=PA43\&hl=id\&source=g bs_toc_r\&cad=4\#v=onepage \&q\&f=false

Gamble, G.O., Hsu, K., Jackson, C., and Tollerson, C.D. 1996. Environmental Disclosures in Annual Reports: An International Perspective. The International Journal of Accounting, 31 (3): 293-331.

Gamerschlag R., Möller, K., and Verbeeten, F. 2010. Determinants of Voluntary CSR Disclosure: Empirical Evidence from Germany. Review of Managerial Science, 4 (3): 130.

Gray, R., and Bebbington, J. 2001. Accounting for the Environment. London: SAGE Publications Ltd. 
Gray, R., Kouhy, R., and Lavers, S. 1995. Corporate Social and Environmental Reporting: A Review of the Literature and a Longitudinal Study of UK Disclosure. Accounting, Auditing and Accountability Journal, 8 (2): 47-77.

Gray, R., Owen, D., and Adams, C. 1996. Accounting and Accountability: Changes and Challenges in Corporate Social and Environmental Reporting. London: Prentice-Hall.

Harvey, B., and A. Schaefer. 2001. Managing Relationships with Environmental Stakeholders: A Study of UK Water and Electricity Utilities. Journal of Business Ethics, 30 (3): 243260.

Hong, S.-C., Wey, K.-D., and Lin, M.-H. 2012. The Effects of Stakeholders and Corporate Performance on Environmental Information Disclosure on Corporate Website. Paper presented at the 2012 International Conference on Business and Information, Sapporo, Japan, 2012.

Huang, C.-L., and Kung, F.-H. 2010. Drivers of Environmental Disclosure and Stakeholder Expectation: Evidence from Taiwan. Journal of Business Ethics, 96: 435-451.

Hughes, S. B., Anderson, A., and Golden, S. (2001). Corporate Environmental Disclosures: Are They Useful in Determining Environmental Performance? Journal of Accounting and Public Policy, 3 (20): 217-240.

IE School of Communication, IULM University, Cambridge University, and Global Alliance. 2010. CSR Communication: Exploring European Cross-National Differences and Tendencies. Spain: IE School of Communication.

Ilinitch, A.Y., Soderstrom, N.S., and Thomas, T.E. 1998. Measuring Corporate Environmental Performance. Journal of Accounting and Public Policy, 17: 383-408.

Ingram, R. W., and Frazier, K. 1980. Environmental Performance and Corporate Disclosure. Journal of Accounting Research, 18 (2): 614-622.

Khemir, S., and Baccouche, C. 2010. Analysis of the determinants of corporate social responsibility disclosure in the annual reports of Tunisian listed firms. Research in Accounting in Emerging Economies, 10: 119 - 144.

Krippendorff, K. 1980. Content Analysis: An Introduction to Its Methodology. Beverly Hills: Sage.

Li, Y., Richardson, G. D., and Thornton, D. 1997. Corporate Disclosure of Environmental Information: Theory and Evidence. Contemporary Accounting Research, 14 (3): 435474.

Liu, X., and Anbumozhi, V. 2009. Determinant Factors of Corporate Environmental Information Disclosure: An Empirical Study of Chinese Listed Companies. Journal of Cleaner Production, 17 (6): 593-600. 
Neu, D., Warsame, H., Pedwell, K. 1998. Managing Public Impressions: Environmental Disclosures in Annual Reports. Accounting, Organizations and Society, 23 (3), 265282.

Mobus, J.L. 2005. Mandatory Environmental Disclosures in a Legitimacy Theory Context. Accounting, Auditing and Accountability Journal, 18 (4): 492-517.

Morhardt, J.E., Baird, S., and Freeman, K. 2002. Scoring Corporate Environmental and Sustainability Report Using GRI 2000, ISO 14031 and Other Criteria. Corporate Social Responsibility and Environmental Management, 9 (4): 215-233.

O'Donovan, G. 2002. Environmental Disclosures in the Annual Report: Extending the Applicability and Predictive Power of Legitimacy Theory. Accounting, Auditing and Accountability Journal, 15 (3): 344-371.

Patten, D.M. 2002. The Relation between Environmental Performance and Environmental Disclosure: A Research Note. Accounting, Organizations and Society, 27: 763-773.

Perotto, E., Canziani, R., Marchesi, R., and Butelli, P. 2008. Environmental Performance, Indicators and Measurement Uncertainty in EMS Context: A Case Study. Journal of Cleaner Production, 16: 517-530.

Pfeffer, J., and Salancik, G. R. 1978. The External Control of Organizations. New York: Harper \& Row.

Roberts, R.W. 1992. Determinants of Corporate Social Responsibility Disclosure. Accounting, Organizations and Society, 17 (6): 595-612

Rockness, J.W. 1985. An Assessment of the Relationship between US Environmental Performance and Disclosure. Journal of Business Finance \& Accounting, 12 (3) 339354.

Sekaran, U., and Bougie, R. 2010. Research Methods for Business: A Skill Building Approach. West Sussex, UK: John Wiley \& Sons Ltd.

The Association of Chartered Certified Accountants (ACCA). 2001. An Introduction to Environmental Reporting. London: ACCA.

Tregidga, H., Milne, M., and Kearins, K. 2006. Organizational Legitimacy and Social and Environmental Reporting Research: The Potential of Discourse Analysis. Paper presented at the 5th Australasian Conference on Social and Environmental Accounting Research, Wellington, 2006 and the 5th Asia-Pacific Interdisciplinary Research in Accounting (APIRA) Conference, Auckland, 2007.

Wagner, M. 2005. How to Reconcile Environmental and Economic Performance to Improve Corporate Sustainability: Corporate Environmental Strategies in the European Paper Industry. Journal of Environmental Management, 76: 105-118. 
Wernerfelt, B. 1984. A Resource-Based View of the Firm. Strategic Management Journal, 5 (2): 171-180.

Wilmshurst, T.D., and Frost, G.R. 2000. Corporate Environmental Reporting: A Test of Legitimacy Theory. Accounting, Auditing \& Accountability Journal, 13 (1): 10 - 26.

Wiseman, J. 1982. An Evaluation of Environmental Disclosures Made in Annual Corporate Reports. Accounting, Organizations and Society, 7 (1): 53-63.

\section{Appendix}

\section{Table 1:}

The Scoring Scale of Environmental Performance Data

\begin{tabular}{|c|c|}
\hline Score & $\begin{array}{l}\text { For each indicator in the disclosure index, points are awarded according to the } \\
\text { scheme below }\end{array}$ \\
\hline 0 & $\begin{array}{l}\text { Performance data, not present (including any non-quantitative references to } \\
\text { performance) }\end{array}$ \\
\hline 1 & Performance and/or governance information is presented only for the current period \\
\hline 2 & $\begin{array}{l}\text { The report and the information contained within it can be compared on a year-to-year } \\
\text { basis }\end{array}$ \\
\hline 3 & $\begin{array}{l}\text { The criteria above, plus the data measurement techniques and bases for calculations } \\
\text { are adequately described and can be replicated with similar results }\end{array}$ \\
\hline 4 & $\begin{array}{l}\text { The criteria above, plus the organization's performance can be compared with } \\
\text { appropriate benchmarks }\end{array}$ \\
\hline
\end{tabular}

Table 2

\begin{tabular}{llc}
\hline Stakeholder Groups & \multicolumn{1}{c}{ Proxy Variables } & Predicted Sign \\
\hline Internal Stakeholders & & \\
Shareholders & Concentrated ownership & - \\
Employees & Number of employees & + \\
External Stakeholders & & \\
Government & Fines and penalties & + \\
Creditors & Financial leverage & $+/-$ \\
Customers & Sales turnover & + \\
Suppliers & Inventory turnover & + \\
Competitors & Market share & + \\
\hline
\end{tabular}

Proxy Variables for Stakeholders 
Table 3

Environmental Disclosure Scoreboard

\begin{tabular}{|c|c|c|c|c|c|c|c|c|}
\hline \multirow[t]{2}{*}{ G3 link } & \multirow{2}{*}{\multicolumn{2}{|c|}{\begin{tabular}{c|c|}
$\begin{array}{c}\text { Aspects concerning } \\
\text { environmental } \\
\text { inputs and outputs }\end{array}$ & \\
\end{tabular}}} & \multicolumn{5}{|c|}{ Firms attaining this item (\%) } & \multirow{2}{*}{\begin{tabular}{|c} 
Average \\
Score
\end{tabular}} \\
\hline & & & 2007 & 2008 & 2009 & 2010 & 2011 & \\
\hline & $\begin{array}{l}\text { Environmental } \\
\text { governance and } \\
\text { credibility }\end{array}$ & $\underset{6}{\operatorname{Max}}$ & & & & & & \\
\hline 4.9 & $\begin{array}{l}\text { Existence of } \\
\text { management } \\
\text { positions for } \\
\text { environmental } \\
\text { protection and } \\
\text { pollution control }\end{array}$ & $0-1$ & $\begin{array}{c}32 \\
(100 \%)\end{array}$ & $\begin{array}{c}32 \\
(100 \%)\end{array}$ & $\begin{array}{c}32 \\
(100 \%)\end{array}$ & $\begin{array}{c}32 \\
(100 \%)\end{array}$ & $\begin{array}{c}32 \\
(100 \%)\end{array}$ & 1 \\
\hline 4.1 & $\begin{array}{l}\text { Existence of an } \\
\text { environmental and/or } \\
\text { public issues } \\
\text { committee in the } \\
\text { board }\end{array}$ & $0-1$ & $\begin{array}{c}28 \\
(87.5 \%)\end{array}$ & $\begin{array}{c}30 \\
(93.7 \%)\end{array}$ & $\begin{array}{c}31 \\
(97 \%)\end{array}$ & $\begin{array}{c}31 \\
(97 \%)\end{array}$ & $\begin{array}{c}32 \\
(100 \%)\end{array}$ & 0.95 \\
\hline 4.8 & $\begin{array}{l}\text { Existence of terms } \\
\text { and conditions } \\
\text { applicable to } \\
\text { suppliers and/or } \\
\text { customers regarding } \\
\text { environmental } \\
\text { practices }\end{array}$ & $0-1$ & $\begin{array}{c}32 \\
(100 \%)\end{array}$ & $\begin{array}{c}31 \\
(97 \%)\end{array}$ & $\begin{array}{c}32 \\
(100 \%)\end{array}$ & $\begin{array}{c}32 \\
(100 \%)\end{array}$ & $\begin{array}{c}31 \\
(97 \%)\end{array}$ & 0.99 \\
\hline 3.13 & $\begin{array}{l}\text { Independent } \\
\text { verification/assurance } \\
\text { about environmental } \\
\text { information in annual } \\
\text { reports }\end{array}$ & $0-1$ & $\begin{array}{c}25 \\
(78 \%)\end{array}$ & $\begin{array}{c}26 \\
(81.2 \%)\end{array}$ & $\begin{array}{c}29 \\
(91 \%)\end{array}$ & $\begin{array}{c}30 \\
(94 \%)\end{array}$ & $\begin{array}{c}32 \\
(100 \%)\end{array}$ & 0.89 \\
\hline 2.1 & $\begin{array}{l}\text { External } \\
\text { environmental } \\
\text { performance awards }\end{array}$ & $0-1$ & $\begin{array}{c}27 \\
(84.4 \%)\end{array}$ & $\begin{array}{c}26 \\
(81.2 \%)\end{array}$ & $\begin{array}{c}26 \\
(81.2 \%)\end{array}$ & $\begin{array}{c}22 \\
(69 \%)\end{array}$ & $\begin{array}{c}23 \\
(72 \%)\end{array}$ & 0.78 \\
\hline 4.13 & $\begin{array}{l}\text { Memberships in } \\
\text { industry associations } \\
\text { and advocacy } \\
\text { organizations to } \\
\text { improve } \\
\text { environmental } \\
\text { practices }\end{array}$ & $0-1$ & $\begin{array}{c}29 \\
(91 \%)\end{array}$ & $\begin{array}{c}27 \\
(84 \%)\end{array}$ & $\begin{array}{c}27 \\
(84 \%)\end{array}$ & $\begin{array}{c}27 \\
(84 \%)\end{array}$ & $\begin{array}{c}29 \\
(91 \%)\end{array}$ & 0.87 \\
\hline & Average Score & & & & & & & 0.91 \\
\hline & Subtotal & & & & & & & 5.47 \\
\hline
\end{tabular}




\begin{tabular}{|c|c|c|c|c|c|c|c|c|}
\hline & Materials & $\begin{array}{c}\mathrm{Max} . \\
\mathbf{8}\end{array}$ & & & & & & \\
\hline EN1 & $\begin{array}{l}\text { Materials used by } \\
\text { weight or volume } \\
\text { (core) }\end{array}$ & $0-4$ & $\begin{array}{c}13 \\
(40.6 \%)\end{array}$ & $\begin{array}{c}20 \\
(62.5 \%)\end{array}$ & $\begin{array}{c}19 \\
(59 \%)\end{array}$ & $\begin{array}{c}20 \\
(62.5 \%)\end{array}$ & $\begin{array}{c}23 \\
(72 \%)\end{array}$ & 1.04 \\
\hline \multirow[t]{4}{*}{ EN2 } & $\begin{array}{l}\text { Percentage of } \\
\text { materials used that } \\
\text { are recycled input } \\
\text { materials (core) }\end{array}$ & $0-4$ & $\begin{array}{c}6 \\
(18.7 \%)\end{array}$ & $\begin{array}{c}5 \\
(15.6 \%)\end{array}$ & $8(25 \%)$ & $\left(\begin{array}{c}12 \\
(37.5 \%)\end{array}\right.$ & $\begin{array}{c}9 \\
(28 \%)\end{array}$ & 0.35 \\
\hline & Average Score & & & & & & & 0.69 \\
\hline & Subtotal & & & & & & & 1.34 \\
\hline & Energy & $\begin{array}{c}\text { Max. } \\
14\end{array}$ & & & & & & \\
\hline EN3 & $\begin{array}{l}\text { Direct energy } \\
\text { consumption by } \\
\text { primary energy } \\
\text { source (core) }\end{array}$ & $0-4$ & $\begin{array}{c}30 \\
(94 \%)\end{array}$ & \begin{tabular}{c|}
30 \\
$(94 \%)$
\end{tabular} & $\begin{array}{c}29 \\
(91 \%)\end{array}$ & $\begin{array}{c}29 \\
(91 \%)\end{array}$ & $\begin{array}{c}29 \\
(91 \%)\end{array}$ & 1.71 \\
\hline EN4 & $\begin{array}{l}\text { Indirect energy } \\
\text { consumption by } \\
\text { primary source (core) }\end{array}$ & $0-4$ & $\begin{array}{c}26 \\
(81.2 \%)\end{array}$ & $\begin{array}{c}26 \\
(81.2 \%)\end{array}$ & $\begin{array}{c}25 \\
(78 \%)\end{array}$ & $\begin{array}{c}25 \\
(78 \%)\end{array}$ & $\begin{array}{c}25 \\
(78 \%)\end{array}$ & 1.41 \\
\hline EN5 & $\begin{array}{l}\text { Energy saved due to } \\
\text { conservation and } \\
\text { efficiency } \\
\text { improvements (add) } \\
\end{array}$ & $0-2$ & $\begin{array}{c}25 \\
(78 \%)\end{array}$ & $\begin{array}{c}21 \\
(65.6 \%)\end{array}$ & $\begin{array}{c}23 \\
(72 \%)\end{array}$ & $\begin{array}{c}21 \\
(65.6 \%)\end{array}$ & $\begin{array}{c}26 \\
(81.2 \%)\end{array}$ & 0.87 \\
\hline EN6 & $\begin{array}{l}\text { Initiatives to provide } \\
\text { energy-efficient } \\
\text { products and services } \\
\text { (add) }\end{array}$ & $0-2$ & $\begin{array}{c}31 \\
(97 \%)\end{array}$ & $\begin{array}{c}29 \\
(91 \%)\end{array}$ & $\begin{array}{c}28 \\
(87.5 \%)\end{array}$ & $\begin{array}{c}29 \\
(91 \%)\end{array}$ & $\begin{array}{c}30 \\
(94 \%)\end{array}$ & 1.02 \\
\hline \multirow[t]{4}{*}{ EN7 } & $\begin{array}{l}\text { Initiatives to reduce } \\
\text { indirect energy } \\
\text { consumption and } \\
\text { reductions achieved } \\
\text { (Add) } \\
\end{array}$ & $0-2$ & $\begin{array}{c}13 \\
(40.6 \%)\end{array}$ & $\begin{array}{c}13 \\
(40.6 \%)\end{array}$ & $\begin{array}{c}15 \\
(46.9 \%)\end{array}$ & $\left(\begin{array}{c}8 \\
(25 \%)\end{array}\right.$ & $\begin{array}{c}9 \\
(28 \%)\end{array}$ & 0.39 \\
\hline & Average Score & & & & & & & 1.08 \\
\hline & Subtotal & & & & & & & 5.41 \\
\hline & Water & $\begin{array}{c}\text { Max. } \\
11\end{array}$ & & & & & & \\
\hline EN8 & $\begin{array}{l}\text { Total water } \\
\text { withdrawal by source } \\
\text { (core) }\end{array}$ & $0-4$ & $\begin{array}{c}21 \\
(65.6 \%)\end{array}$ & $\begin{array}{c}24 \\
(75 \%)\end{array}$ & $\begin{array}{c}25 \\
(78 \%)\end{array}$ & $\begin{array}{c}28 \\
(87.5 \%)\end{array}$ & $\begin{array}{c}30 \\
(93.7 \%)\end{array}$ & 1.52 \\
\hline EN9 & $\begin{array}{l}\text { Water sources } \\
\text { significantly affected } \\
\text { by withdrawal of } \\
\text { water }(\text { add) } \\
\end{array}$ & $0-1$ & $\begin{array}{c}12 \\
(37.5 \%)\end{array}$ & $\begin{array}{c}13 \\
(40.6 \%)\end{array}$ & $\begin{array}{c}14 \\
(43.7 \%)\end{array}$ & $\begin{array}{c}17 \\
(53 \%)\end{array}$ & $\begin{array}{c}16 \\
(50 \%)\end{array}$ & 0.45 \\
\hline EN10 & $\begin{array}{l}\text { Percentage and total } \\
\text { volume of water }\end{array}$ & $0-2$ & $\begin{array}{c}10 \\
(31.2 \%)\end{array}$ & $\begin{array}{c}12 \\
(37.5 \%) \\
\end{array}$ & $\begin{array}{c}11 \\
(34.4 \%) \\
\end{array}$ & $\begin{array}{c}12 \\
(37.5 \%)\end{array}$ & $\begin{array}{c}16 \\
(50 \%) \\
\end{array}$ & 0.56 \\
\hline
\end{tabular}




\begin{tabular}{|c|c|c|c|c|c|c|c|c|}
\hline & $\begin{array}{l}\text { recycled and reused } \\
\text { (add) }\end{array}$ & & & & & & & \\
\hline \multirow[t]{4}{*}{ EN21 } & $\begin{array}{l}\text { Total water discharge } \\
\text { by quality and } \\
\text { destination (core) }\end{array}$ & $0-4$ & $\begin{array}{c}21 \\
(65.6 \%)\end{array}$ & $\begin{array}{c}23 \\
(72 \%)\end{array}$ & $\begin{array}{c}22 \\
(68.7 \%)\end{array}$ & $\begin{array}{c}24 \\
(75 \%)\end{array}$ & $\begin{array}{c}27 \\
(84.4 \%)\end{array}$ & 1.33 \\
\hline & Average Score & & & & & & & 0.96 \\
\hline & Subtotal & & & & & & & 3.86 \\
\hline & Biodiversity & Max. & & & & & & \\
\hline EN11 & $\begin{array}{l}\text { Location and size of } \\
\text { land owned, leased, } \\
\text { managed in areas of } \\
\text { high biodiversity } \\
\text { value outside } \\
\text { protected areas (core) }\end{array}$ & \begin{tabular}{|l|}
$0-2$ \\
\end{tabular} & $\begin{array}{c}15 \\
(46.9 \%)\end{array}$ & $\begin{array}{c}13 \\
(40.6 \%)\end{array}$ & $\begin{array}{c}13 \\
(40.6 \%)\end{array}$ & $\begin{array}{c}14 \\
(43.7 \%)\end{array}$ & $\begin{array}{c}18 \\
(56.2 \%)\end{array}$ & 0.52 \\
\hline \multirow[t]{4}{*}{ EN12 } & $\begin{array}{l}\text { Description of } \\
\text { significant impacts of } \\
\text { activities, products, } \\
\text { and services on } \\
\text { biodiversity in areas } \\
\text { of high biodiversity } \\
\text { value (core) }\end{array}$ & $0-2$ & $\begin{array}{c}22 \\
(68.7 \%)\end{array}$ & $\begin{array}{c}25 \\
(78 \%)\end{array}$ & $\begin{array}{c}27 \\
(84.4 \%)\end{array}$ & $\begin{array}{c}28 \\
(87.5 \%)\end{array}$ & $\begin{array}{c}27 \\
(84.4 \%)\end{array}$ & 0.82 \\
\hline & Average Score & & & & & & & 0.67 \\
\hline & Subtotal & & & & & & & 1.34 \\
\hline & $\begin{array}{l}\text { Emissions, } \\
\text { Effluents, and } \\
\text { Waste } \\
\end{array}$ & $\begin{array}{c}\text { Max. } \\
16\end{array}$ & & & & & & \\
\hline EN16,17 & $\begin{array}{l}\text { Total direct and } \\
\text { indirect greenhouse } \\
\text { gas emissions by } \\
\text { weight (core) }\end{array}$ & $0-4$ & $\begin{array}{c}31 \\
(97 \%)\end{array}$ & $\begin{array}{c}31 \\
(97 \%)\end{array}$ & $\begin{array}{c}31 \\
(97 \%)\end{array}$ & \begin{tabular}{|c|}
31 \\
$(97 \%)$
\end{tabular} & $\begin{array}{c}31 \\
(97 \%)\end{array}$ & 1.96 \\
\hline EN18 & $\begin{array}{l}\text { Initiatives to reduce } \\
\text { greenhouse gas } \\
\text { emissions and } \\
\text { reductions achieved } \\
\text { (add) }\end{array}$ & $0-2$ & $\begin{array}{c}30 \\
(93.7 \%)\end{array}$ & $\begin{array}{c}31 \\
(97 \%)\end{array}$ & $\begin{array}{c}32 \\
(100 \%)\end{array}$ & $\begin{array}{c}32 \\
(100 \%)\end{array}$ & $\begin{array}{c}28 \\
(87.5 \%)\end{array}$ & 1.21 \\
\hline EN19,20 & $\begin{array}{l}\text { Emissions of ozone- } \\
\text { depleting substances } \\
\text { and other significant } \\
\text { air emissions (core) }\end{array}$ & $0-4$ & $\begin{array}{c}31 \\
(97 \%)\end{array}$ & $\begin{array}{c}29 \\
(90.6 \%)\end{array}$ & $\begin{array}{c}28 \\
(87.5 \%)\end{array}$ & $\begin{array}{c}25 \\
(78 \%)\end{array}$ & $\begin{array}{c}29 \\
(90.6 \%)\end{array}$ & 1.76 \\
\hline EN22 & $\begin{array}{l}\text { Total weight of waste } \\
\text { by type and disposal } \\
\text { method (core) }\end{array}$ & $0-4$ & $\begin{array}{c}27 \\
(84.4 \%)\end{array}$ & $\begin{array}{c}28 \\
(87.5 \%)\end{array}$ & $\begin{array}{c}27 \\
(84.4 \%)\end{array}$ & $\begin{array}{c}30 \\
(93.7 \%)\end{array}$ & $\begin{array}{c}31 \\
(97 \%)\end{array}$ & 1.71 \\
\hline EN23 & $\begin{array}{l}\text { Total number and } \\
\text { volume of significant } \\
\text { spills (core) }\end{array}$ & $\mid 0-2$ & $\begin{array}{c}16 \\
(50 \%)\end{array}$ & $\begin{array}{c}16 \\
(50 \%)\end{array}$ & $\begin{array}{c}17 \\
(53 \%)\end{array}$ & $\begin{array}{c}19 \\
(59.4 \%)\end{array}$ & $\begin{array}{c}20 \\
(62.5 \%)\end{array}$ & 0.77 \\
\hline
\end{tabular}




\begin{tabular}{|c|c|c|c|c|c|c|c|c|}
\hline & Average Score & & & & & & & 1.48 \\
\hline & Subtotal & & & & & & & 7.41 \\
\hline & $\begin{array}{l}\text { Products, Services, } \\
\text { and Transport }\end{array}$ & $\underset{3}{3}$ & & & & & & \\
\hline EN26 & $\begin{array}{l}\text { Initiatives to mitigate } \\
\text { environmental } \\
\text { impacts of products } \\
\text { and services (core) }\end{array}$ & $0-2$ & $\begin{array}{c}27 \\
(84.4 \%)\end{array}$ & $\begin{array}{c}30 \\
(93.7 \%)\end{array}$ & $\begin{array}{c}31 \\
(97 \%)\end{array}$ & $\begin{array}{c}32 \\
(100 \%)\end{array}$ & $\begin{array}{c}31 \\
(97 \%)\end{array}$ & 0.96 \\
\hline \multirow[t]{6}{*}{ EN29 } & $\begin{array}{l}\text { Significant } \\
\text { environmental } \\
\text { impacts of } \\
\text { transporting products } \\
\text { and other goods and } \\
\text { materials, and } \\
\text { members of the } \\
\text { workforce (add) }\end{array}$ & $0-1$ & $\left|\begin{array}{c}18 \\
(56.2 \%)\end{array}\right|$ & $\begin{array}{c}18 \\
(56.2 \%)\end{array}$ & $\begin{array}{c}16 \\
(50 \%)\end{array}$ & $\begin{array}{c}19 \\
(59.4 \%)\end{array}$ & $\begin{array}{c}18 \\
(56.2 \%)\end{array}$ & 0.56 \\
\hline & Average Score & & & & & & & 0.76 \\
\hline & Subtotal & & & & & & & 1.51 \\
\hline & Total & Max. & & & & & & \\
\hline & Mean & & & & & & & 26.4 \\
\hline & Standard Deviation & & & & & & & 5.85 \\
\hline
\end{tabular}

Table 4

Regression Result of Fixed Effects Model (Zero Replacement)

\begin{tabular}{|c|c|c|}
\hline \multicolumn{3}{|l|}{ Dependent Variable: ED } \\
\hline \multicolumn{3}{|l|}{ Method: Pooled Least Squares } \\
\hline \multicolumn{3}{|l|}{ Sample: 20072011} \\
\hline \multicolumn{3}{|l|}{ Included observations: 5} \\
\hline \multicolumn{3}{|l|}{ Cross-sections included: 32} \\
\hline \multicolumn{3}{|l|}{ Total pool (balanced) observations: 160} \\
\hline Variable & Predicted Sign & Coefficient \\
\hline $\mathrm{C}$ & & $-3.606716^{(0.8634)}$ \\
\hline Shareholders (Blockholder Ownership) & - & $-0.014845^{(0.7199)}$ \\
\hline Employees (Number of Employees) & + & $-4.68 \mathrm{E}-05^{(0.1652)}$ \\
\hline Government (Fines and Penalties) & + & $147.9582 * * *(0.0017)$ \\
\hline Creditors (Financial Leverage) & $+1-$ & $0.393756^{(0.548)}$ \\
\hline Customers (LN Sales Turnover) & + & $4.839244 * *(0.0274)$ \\
\hline Suppliers (Inventory Turnover) & + & $1.227919^{(0.4546)}$ \\
\hline Competitors (Market Share) & + & $-44.90012^{(0.6029)}$ \\
\hline $\begin{array}{l}\text { Environmental Performance } 1 \\
\text { (Energy Consumption normalized by size) }\end{array}$ & $+/-$ & $1.001929 * *(0.0337)$ \\
\hline Environmental Performance2 & $+1-$ & $-1.204375^{(0.5159)}$ \\
\hline
\end{tabular}


The Indonesian Journal of Accounting Research - September, Vol. 20, No.3, 2017.

\begin{tabular}{|l|r|r|}
\hline (Total $\mathrm{CO}_{2}$ Emission normalized by size) & & \\
\hline Size (LN Total Assets) & $+/-$ & $-1.831862^{(0.4841)}$ \\
\hline Inclusion in Sustainability Index (FTSE4Good) & $+/-$ & $0.498027^{(0.6949)}$ \\
\hline & & 0.811169 \\
\hline R-squared & & 0.743384 \\
\hline Adjusted R-squared & & 3.129824 \\
\hline S.E. of regression & & 11.96672 \\
\hline F-statistic & & 0.000000 \\
\hline Prob. (F-statistic) & & 1.479842 \\
\hline Durbin-Watson stat & & \\
\hline
\end{tabular}

